\title{
Olfactory perception and inclusive fitness
}

\author{
D. H. THOR \\ Edward R. Johnstone Training and Research Center, Bordentown, New Jersey 08505
}

\begin{abstract}
Within an established colony, sexually mature male rats interact with little or no conflict, but unfamiliar males are readily attacked and subjected to prolonged and physiologically deteriorating social stress. Evidence is offered in support of the ontogeny, stimulus characteristics, and adaptive significance of this social discrimination. It is asserted (1) that two odor categories are implicated in the determination of identity, (2) that dominant males are exposed to individual odors of juveniles prior to their attainment of a postpubertal androgen based odor, and (3) that such exposure is the basis for subsequent immunity from attack. Sequence of odor development in young males, therefore, reveals the biological mechanism that governs the selective display of territorial aggression. Males maturing within the confines of an established territory, and likely to be the offspring of the alpha or his siblings, thus gain a higher probability of reaching reproductive maturity and eventual alpha status. This epigenetic phenomenon confers selective advantage and promotes inclusive fitness.
\end{abstract}

Unfamiliar male rats are readily attacked by dominant (alpha) males of an established colony containing males and females (Barnett, 1955, 1958; Blanchard, Fukunaga, Blanchard, \& Kelley, 1975; Calhoun, 1962; Lore \& Luciano, 1977; Luciano \& Lore, 1975; Steiniger, 1950). The intensity of aggression is often severe and persistent, with death inflicted by direct wounding, stress-related deterioration, or blocked access to available nutrients. If an escape route is available, the attacked intruder retreats and avoids subsequent intrusions. In marked contrast, male members of an established group (var: clan, pack, family, or colony) generally behave amicably toward each other.

When reliably aggressive alpha males are subjected to sensory treatments which interfere with their olfactory perception, intruder-elicited aggression fails to occur (Alberts \& Galef, 1973; Flannelly \& Thor, 1976); similarly, if the mature male intruder is a prepubertal castrate, no attack occurs (Flannelly \& Thor, 1978); but if the nonattacked castrate is treated with exogenous testosterone, he is then attacked (Barfield, Busch, \& Wallen, 1972). These experiments suggest that gonadal androgens are directly implicated in stimulating the production of odors from urine and/or sebaceous glands that precipitate alpha attack (Gawienowski, Orsulak, Stacewicz-Sapuntzakis, \& Joseph, 1975).

\section{Developmental Sequence of Odor Identiy}

Neonatal rat pups may not have any odors identifying them as conspecifics, since they are readily consumed by a significant proportion of hungry adults, particularly males (Rosenberg \& Sherman, 1975). At approximately 15 days of age, and coinciding with hair growth, eye opening, and a rapid increase in mobility, rat pups may attain their initial olfactory sig- nature (Carr, Yee, Gable, \& Marasco, 1976; MüllerSchwarze, 1974; Myer, 1964). From this age to puberty, male and female pups are neither consumed by adults nor subject to biting attack when placed in a strange colony. Selected aggressive males that readily attack any unfamiliar mature male will not attack juvenile males (Thor \& Flannelly, 1976). Attack potential is high thereafter and appears to occur in concordance with the pubertal elevation in gonadal hormone, at approximately 60-80 days of age in laboratory rats (Grota, 1971).

Although no chemically defined classification of social odors is available for the rat (Bronson, 1971; Carr, 1974; Cheal, 1975; Eisenberg \& Kleiman, 1972), it may be assumed that one category of odors is related to individual biochemistry as well as current sources of nutrients (hereafter referred to as individual odor) and that this olfactory stimulus complex is sufficiently unique for identifying the individual to others (see Müller-Schwarze, 1974). Another category of odors may be assumed to exist that is related to gonadal hormone output, and although not necessarily unique, it maintains a quality signifying male gender (hereafter referred to as androgen odor; see Carr \& Caul, 1962). Other social odors (e.g., female sex-related) undoubtably exist and have important biological functions (Thor \& Flannelly, 1977).

It is further assumed that the juvenile interval of immunity from attack by any adult male has at least two important functions: (1) to allow free exposure to mature males living nearby (for review of mere exposure effects, see Hill, 1978), and (2) to allow the juvenile to freely immigrate and readily gain acceptance by dominant males of nearby colonies. When puberty is attained, the androgen odor is thereafter tolerated by dominant males that have previously 
gained familiarity with the individual odor. Adolescent or mature males, with no comparable social exposure to alphas prior to attaining the androgen odor, constitute an intolerable social stimulus presence. Thus, only conspecifics with unfamiliar conspecific identity and recognized as male are attacked by dominant males.

\section{Adaptive Significance}

Unfamiliar, mature male conspecifics constitute a distinct genetic threat to the alpha male. By vigorous biting attacks and sustained threat, the alpha accomplishes the withdrawal of strange males (Blanchard \& Blanchard, 1977). Strange females, in marked contrast, are not only readily accepted but appear to have surplus excitatory capacity, as indicated by the Coolidge effect (for a review, see Sachs \& Barfield, 1976). Castrate males, castrate females, and juveniles all have an initial stimulating effect that dissipates within a few minutes; no sexually neutral conspecific is subject to threat or attack.

Denial of territorial encroachment to other mature males serves to maintain reproductive exclusivity over extended intervals, including intervals when colony females are anestrus (diestrus, pregnant, lactating, or immature) or when the alpha is sexually exhausted. Immediately after an alpha ejaculates (during the postejaculatory sexual-refractory interval), he will attack a strange male intruder, and such attack also occurs after several ejaculations (Thor \& Flannelly, 1979). Sexual exhaustion, therefore, does not necessarily inhibit attack upon a strange male. It appears that the presence of females and gain in sexual experience increases gonadal hormone output (Folman \& Drori, 1969), which, in turn, increases the tendency to behave aggressively in the event of confrontation with unfamiliar males (Flannelly \& Lore, 1977). Testosterone also stimulates growth and muscle density, thereby increasing the probability of success in conflict with other males. Repeated victorious encounters with unfamiliar males increase the probability of continued future success, mediated (in part) by a testosterone-accentuated persistence (Andrew, 1978).

\section{Fitness, Inclusive Fitness, and Kin Selection}

Darwinian fitness, in the sociobiological application, refers to reproductive success, or more specifically, to the probability of contributing to the gene pool of future generations (see Wilson, 1975). Inclusive fitness, as defined by Hamilton (1964), extends the concept to genes shared with close relatives. Therefore, the behavior of individuals can be interpreted, on occasion, as contributing to inclusive fitness, or the probability of extending shared genetic representation in future gene pools (see Haldane, 1932). Kin selection is defined as behavioral processes that favor the survival and reproduction of relatives who share the same genes by common descent (Maynard Smith, 1964).

Dominant alpha male rats may normally learn to tolerate cohabitant males because of their exposure to such males when they are juveniles. A familiarity with their individual odors may constitute the primary means of conferring acceptance to young males who are likely to be alpha offspring or offspring of a close relative and will eventually supercede the current alpha as the most dominant and reproductively sucessful male. The olfactory recognition by the alpha of individual odor is therefore of considerable consequence in contributing to selection.

\section{An Epigenetic Bias}

As described by Moltz (1965), "the epigenetic approach holds that all response systems are synthesized during ontogeny and that this synthesis involves the integrative influence of both intraorganic processes and extrinsic stimulative conditions"' (p. 44). A more lengthy and definitive account has been provided by Kuo (1967, p. 11ff). More recently, Daly and Wilson (1978) stated that an "item of behavior cannot be fully comprehended until we grasp its adaptive significance and its physiology and its evolutionary history and its stimulus control and its ontogeny." Tinbergen (1968, p. 412) defined the major goals of ethology in remarkably similar terms.

In the present interpretation, the protection apparently gained during juvenile development (that extends into maturity) is viewed as a geographic coincidence of proximity that occurs because of the location of nest site within the territorial or home range bounds of the alpha male. The normal presence of the pups over an interval of several days is probably sufficient for establishing familiarity. Weanling male pups not directly related to alpha that mature in his presence are not attacked when they later reach puberty (personal observation). Therefore, the proposed theory is not contingent upon direct lineage and may be considered essentially an associativelearning phenomenon. Mounting evidence for Zajonc's hypothesis (1968) that mere exposure increases preference (Hill, 1978) suggests that experience with particular stimuli influences their subsequent social valence. The present case offers a highly distinctive model for analyses of specific variables that apparently lie at the foundations for territorial aggression in rats, and perhaps a number of related species.

Telle $(1966$, p. 90$)$ reports in considerable detail a number of observations made of wild rat colonies. He refers to olfactory identity recognition as a prime determinant of territorial behavior. In this regard, Telle concluded that the "defense of territory" was inversely correlated with the size of the colony. When colony membership was 80 or more, foreign rats were 
not attacked. Presumably, when memory load capacity is exceeded, alpha is incapable of recognizing foreigners and no longer exhibits intermale aggression. Lore and Flannelly (1977) have recently referred to Telle's findings in support of their thesis that efficient social organization may be the most salient feature of environmental adaptibility. These investigators found that, under optimal conditions, burrow systems remained similar but occurred in greater density, suggesting a constancy in social units with shifting size of defended territories.

Elsewhere, it has been argued that the concept of territoriality, as applied to rats, is in need of conceptual modifications (Thor, in press). The suggested alternative to the traditional population dispersal function is an active competition among males for sexual access to receptive females. Territorial marking by males is androgen related and may be viewed as a means of attracting females (Brown, 1977); social dominance among males may be linked to sexual selection (Thor \& Carr, 1979).

The proposed explanation for the dichotomous behavior of alpha males toward familiar and unfamiliar males rests on the assumption of olfactory identity which is present prepubertally and is socially acknowledged by alpha prior to attainment of an androgen-related odor. Unfamiliar, mature males emitting a significant concentration of the latter odor constitute potential competitors for available females. Thus, it is genetically appropriate that such competitors be excluded from the home territory. Familiar, colony males are more likely to share kinship, to be amicable, to be submissive, and to eventually attain alpha status and reproductive priority within the colony.

\section{Conclusion}

The present analysis considers the import of prepubertal maturation in the rat pup and associated change in stimulus quality of the individual as perceived by mature conspecifics. It specifies that the socially aggressive behavior of the alpha is governed by a recognition form of learning that discriminates among olfactory cues of biochemical origin. Young pups attain individual recognition prior to sexual maturity, and such recognition serves as an olfactory shield when postpubertal androgen-related odors are superimposed. This protection is a form of selection that rests upon the retentive (long-term) memory store of the alpha and his discriminative capacity for recognizing differences in odor that are descriptive of individual rats. How this intricate social, physiological, and genetic interaction evolved is beyond the scope of this presentation. It is reasonable to assume, however, that a similar role for olfactory perception may be applicable to related species with highly developed chemosensory systems.

\section{REFERENCES}

Alberts, J. R., \& Galef, B. G., JR. Olfactory cues and movement: Stimuli mediating intraspecific aggression in the wild Norway rat. Journal of Comparative and Physiological Psychology, 1973, 85, 233-242.

ANDREW, R. J. Increased persistence of attention produced by testosterone and its implications for the study of sexual behavior. In J. B. Hutchinson (Ed.), Biological determinants of sexual behaviour. New York: Wiley, 1978.

BARfield, R. J., Busch, D. E., \& Wallen, K. Gonadal influence on agonistic behavior in the male domestic rat. Hormones and Behavior, 1972, 3, 247-259.

BARnett, S. A. Competition among wild rats. Nature, 1955, 175, 126-127.

BARnetT, S. A. An analysis of social behavior in wild rats. Proceedings of the Zoological Society of London, 1958, 130, 107-152.

Blanchard, R. J., Fukunaga, K., Blanchard, D. C., \& Kelley, M. J. Conspecific aggression in the laboratory rat. Journal of Comparative and Physiological Psychology, 1975, 89, 1204-1209.

Blanchard, R. J., \& Blanchard, D. C. Aggressive behavior in the rat. Behavioral Biology, 1977, 21, 197-224.

Bronson, F. H. Rodent pheromones. Biology of Reproduction, 1971, 4, 344-357.

Brown, R. E. Odor preference and urine-marking scales in male and female rats: Effects of gonadectomy and sexual experience on responses to conspecific odors. Journal of Comparative and Physiological Psychology, 1977, 91, 1190-1206.

Calmoun, J. B. The ecology and sociology of the Norway rat. (U.S. Public Health Service Publication No. 1008). Washington, D.C: U.S. Government Printing Office, 1962.

CARR, W. J. Pheromonal sex attractants in the Norway rat. In L. Krames, P. Pliner, \& T. Alloway (Eds.), Advances in the study of communication and affect: Nonverbal communication (Vol. 1). New York: Plenum, 1974.

Carr, W. J., \& Caul, W. F. The effect of castration in rat upon the discrimination of sex odours. Animal Behaviour, 1962, 10, 20-27.

Carr, W. J., Yee, L., Gable, D., \& Marasco, E. Olfactory recognition of conspecifics by domestic Norway rats. Journal of Comparative and Physiological Psychology, 1976, 90, 821-828.

Che AL, M. Social olfaction: A review of the ontogeny of olfactory influences on vertebrate behavior. Behavioral Biology, 1975, 15, $1-25$.

Daly, M., \& WILSON, M. Sex, evolution and behavior. North Scituate, Mass: Duxbury Press, 1978.

EisenberG, J. F., \& Kleiman, D. G. Olfactory communication in mammals. Annual Review of Ecology and Systematics, 1972, 3, 1-32.

Flannelly, K., \& Lore, R. The influence of females upon aggression in domesticated male rats (Rattus norvegicus). Animal Behaviour, 1977, 25, 654-659.

Flannelly, K. J., \& ThOR, D. H. Territorial behavior of laboratory rats under conditions of peripheral anosmia. Animal Learning \& Behavior, 1976, 4, 337-340. (a)

Flannelly, K. J., \& ThOR, D. H. Territorial aggression of the rat to males castrated at various ages. Physiology \& Behavior, 1978, 20, 785-789. (b)

Folman, Y., \& Drori, D. The testosterone content of the testes of mated and unmated rats. Journal of Endocrinology, 1969, 44, 127-128.

Gawienowski, A. M., Orsulak, P. J., StacewiczSapuntzakis, M., \& Joseph, B. M. Presence of sex pheromone in preputial glands of male rats. Journal of Endocrinology, 1975, 67, 283-288.

Grota, L. J. Effects of age and experience on plasma testosterone. Neuroendocrinology, 1971, 8, 136-143. 
HALDANE, J. B. S. The causes of evolution. London: Longmans, Green, 1932.

Hamilton, W. D. The genetical theory of social behaviour: I and II. Journal of Theoretical Biology, 1964, 7, 1-52.

HILL, W. F. Effects of mere exposure on preferences in nonhuman mammals. Psychological Bulletin, 1978, 85, 1177-1198.

Kuo, Z. Y. The dynamics of behavior development. New York: Random House, 1967.

Lore, R., \& Flannelly, K. Rat societies. Scientific American, 1977, 236, 106-116.

LORE, R., \& LuCiano, D. Attack stress induces gastrointestinal pathology in domesticated rats. Physiology \& Behavior, 1977, 18, 743-745.

Luciano, D., \& Lore, E. Aggression and social experience in domesticated rats. Journal of Comparative and Physiological Psychology, 1975, 88, 917-923.

MAYNARD Smith, J. Group selection and kin selection. Nature, 1964, 201, 1145-1147.

Moltz, H. Contemporary instinct theory and the fixed action pattern. Psychological Review, 1965, 72, 27-47.

Mülle R SCHWARze, D. Olfactory recognition of species, groups, individuals, and physiological states among mammals. In M. C. Birch (Ed.), Pheromones. Amsterdam: North-Holland, 1974.

MYER, J. S. Stimulus control of mouse-killing rats. Journal of Comparative and Physiological Psychology, 1964, 58, 112-117.

Rosenberg, K. M., \& Sherman, G. F. Influence of testosterone on pup killing in the rat is modified by prior experience. Physiology \& Behavior, 1975, 15, 669-672.

SACHS, B. D., \& BARFIELD, R. J. Functional analysis of masculine copulatory behavior in the rat. In J. S. Rosenblatt, R. A. Hinde, E. Shaw, \& C. Beer (Eds.), Advances in the study of behavior (Vol. 7). New York: Academic Press, 1976.
Steiniger, F. Beiträge zur Soziologie und sonstigen Biologie der Wanderratte. Zeitschrift für Tierpsychologie, 1950, 7, 356-379.

TELLe, H. J. Contributions to the knowledge of behavioral patterns in two species of rats, Rattus norvegicus and Rattus rattus. Zeitschrift für angewandte Zoologie (V. N. Nekrassoff, trans.), 1966, 53, 129-196.

THOR, D. H. Threat and attack in the alpha male rat. Bulletin of the Psychonomic Society, 1979, 24, 146-148.

Thor, D. H., \& CARR, W. J. Sex and aggression: Competitive mating strategy in the male rat. Behavioral and Neural Biology, 1979, 26, 261-265.

Thor, D. H., \& Flannelly, K. J. Age of intruder and territorialelicited aggression in male Long-Evans rats. Behavioral Biology, 1976, 17, 237-241.

Thor, D. H., \& Flannelly, K. J. Social-olfactory experience and initiation of copulation in the virgin male rat. Physiology \& Behavior, 1977, 19, 411-417.

Thor, D. H., \& Flannelly, K. J. Copulation and intermale aggression in rats. Journal of Comparative and Physiological Psychology, 1979, 93, 223-228.

Tinbergen, N. On war and peace in animals and man. Science, 1968, 160, 1411-1418.

Wilson, E. O. Sociobiology: The new synthesis. Cambridge, Mass: Belknap, 1975.

ZAJONC, R. B. Attitudinal effects of mere exposure. Journal of Personality and Social Psychology Monograph Supplement, 1968, 9(2, Pt. 2), 1-27.

(Received for publication April 27, 1979; revision accepted June 26, 1979.) 